\title{
The Correlation between Students Reading Habit and Their Writing Ability of Narrative Text
}

\author{
Muhammad Taufik Ihsan \\ State Islamic University of Sultan Syarif Kasim Riau, Indonesia \\ muhammadtaufikihsan@gmail.com
}

\begin{abstract}
The researcher's conducted a research at State Islamic Senior High School 1 Pekanbaru. The formulation the problems are : How is the students reading habit? How is the students' ability of writing narrative text? Is there any significant correlation between students reading habit and their ability in writing narrative text? The design of this reseach study was correlational research. The total number of population was 262 students. The researcher used purposive sampling by taking only one class as sample 34 . To analyze the data, the researcher used questionnaire and written test. Questionnaire is used to collect the data about students reading habit. The written test of narrative text was intended to find out students writing ability of narrative text. Based on data analysis, the writer found that the average score of the students' questionnaire for students reading habit is 60.1. it is categorized into good level. students writing ability is 72.4 , the score is categorized good level. the correlation between students reading habit and their ability of writing applied to the sample is 0.629 , and consulting to the critical values of the $r$ Product Moment with 95\% confidence level and the number of subjects 34 was 0.339 . Therefore, the writer concludes that there is a significant positive correlation between students reading habit $(\mathrm{X})$ and their ability of writing narrative text (Y).
\end{abstract}

Keywords: Correlation, Reading Habit, Writing Narrative Text.

\section{INTRODUCTION}

Reading is an important gateway to personal development, and to social, economic and civic life Holden ( 2004:5). It allows us to learn about other people,about history and social studies, the language arts, sciences, mathematics, and the other content subjects that must be mastered in school. Reading skill is important throughout the lifespan, recreational reading has been found to improve reading comprehension, writing style, vocabulary, spelling, and grammatical development Gallik (1999:1). Reading provides writers with knowledge of the language of writing, the grammar, 
vocabulary, and discourse style writers use. By taking a look in this power of reading, Krashen (2004:11) states.

Writing skill as stated before is productive knowledge of words.

Webb (2008:79) said that Learners who have larger receptive vocabulary are likely to know more of those words productively than learners who have smaller receptive vocabulary This shows that those who read more acquire more of the written language as Smith (1994:560) undoubtedly right when he advises "To learn to write for newspapers, you must read newspapers; textbooks about them will not suffice.

Because of the students have the low skills in interferential reading comprehension; the writer has opinion that reading habit supports the student to be able to comprehend the text. That is the reason why the writer wants to show that reading habit is very important to support inferential reading comprehension.

In fact, students are still confused and cannot understand about narrative text that can be seen from problems below:

1. Some of the students are not able to use the chronological order in writing narative text.

2. Some of the students not able to make the presentation, complication, and resolution even though they have studied about narrative text.

3. Some of students are not able to develop topic sentence to be a paragraph past tense and use verb action.

\section{RESEARCH METHOD}

This research is a correlation research. According to Sugiono (2010:72) correlation research is a research that has no treatment, different from experimental research that has a treatment. Creswell (2011:338) stated that correlation reaasearch design is quantitative design which investigatiors use a correlation statistical technique to describe and measure the degree of association (or relationship) between two or more variables orsets of score. There are two variables in this research,they are independent variable (X) is students reading habit and the dependent variable (Y)

This research was conducted at State Islamic Senior High School 1 Pekanbaru, which is located at J1. Bandeng Pekanbaru city. This research was conducted on February 2018.

The desired sample in this research is 262 students. The population above is too large to be taken as a sample of the research. The researcher used a purposive sampling. Gay (2012, p.141) states the process of selecting sample that is believed to be representative of given a population. In the other words, the researcher selects the sample using is experience and knowledge of the group to be sample. The researcher took only one class in the Eleventh grade social 1 class. The total number of students of the tenth grade social 1 class consists of 34 students.

These five components can be used as the indicators of writing narrative 
text. Because the students will be given several questions such as setting questions, character questions, plot questions, theme questions, and vocabulary questions. According to Syafi'i, narrative has certain elements in common, they are; unfold over time,display emotion, and centre on event more than ideas.Unfold over time means the stories or events happenened in a certain order and chronological order must be communicated to the reader. Events are listed in sequence of how they happened and specific scenes are set in time and in place and recreated for the reader. Display emotion refers to how the writers are able to connect some short of emotion felt by the subject on events to reader. Centre on events means the writers should make the events to be detailed; they also have applied a broader meaning to the events.

Based on the theories, we can conclude that narrative have some charateristtics, they are:

a. The narrative text tells sequence of an event.

b. The narrative text uses the chronological order.

c. The narrative texts are usually based on the personal experience.

d. The narrative text is written in the past action.

\section{TECHNIQUE OF COLLECTING THE DATA}

In this research, The writer used questionnaire and test to collect data for the research. Questionnaire is used to collect the data about students reading habit. According Gay and Airasian (2011: 630) questionnaire is a written collection of self-report question to be answered by a selected group of research participants. While Nunan (1992:231) stated that questionnaire is an instrument for collecting data, usually in written form, consisting of open and or closed questions and other probes requiring a response from subject. The questionnaire is an instrument for collecting the self-report data that consist of some questions in written form. the questioner obtained with respondents opinion in responding to the following options:
A. Always
B. Often
C. Sometimes
D. Never

The written test of narrative text was intended to find out students writing ability of narrative text. There is no specific topic provided, and the participants freely to create their own writing and developed into a short narrative text composition. The participants asked to write a short composition of narrative text with the length of words at least 100 words in 45 minutes.

The text is analysed based on the social function, generic structure, and significant lexicogrammatical features. Then each of text is also analysed from these three aspects:

1) Format and content

2) Organization and coherence

3) Sentence construction and vocabulary 


\section{TECHNIQUE OF DATA ANALYZING}

The collected data will be analyzed in two steps as follows:

\section{Individual Competence}

To measure the students' reading habit, the writer used questionnaire and to find the result, writer used the individual competence, (Arikunto 2006: 225) by the following formula:

$$
\mathrm{P}=\frac{\mathrm{n}}{N} \times 100 \%
$$

Where:

$\mathrm{P}$ : The percentage of the student's reading habit

$\mathrm{n}$ : The achieved score

$\mathrm{N}$ : The maximum score in the test

Then to know the percentage of students reading habit, Arikunto (2006: 230) suggested these five categories.

\subsection{Five Categories Percentage}

\begin{tabular}{|l|l|}
\hline Category & Range \\
\hline Very Good & $81 \%-100 \%$ \\
Fair & $61-80 \%$ \\
Bad & $41-60 \%$ \\
Very Bad & $21-40 \%$ \\
\hline
\end{tabular}

2. Validity of the Test
Validity is a measurement that shows the degree of instrument validity. An instrument can be said as the valid one if it can show the data from the research variable accurately Arikunto (2006:168). To measure the validity test, the writer used Product Moment Formula. The formula is as follows:

$$
\begin{aligned}
& r=\frac{\mathrm{n} \Sigma \mathrm{xy}-(\Sigma \mathrm{x})(\Sigma \mathrm{y})}{\sqrt{ }\left\{\mathrm{n} \Sigma \mathrm{x}^{2}-(\Sigma \mathrm{x})^{2}\right\} \quad \mathrm{n} \Sigma \mathrm{y}^{2}-} \\
& \left.(\Sigma \mathrm{y})^{2}\right\}
\end{aligned}
$$

(Arikunto 2006: 72)

In which:

rxy : correlation coefficient between $\mathrm{X}$ and $\mathrm{Y}$

$\Sigma X Y$ : the result of multiplying scores between $\mathrm{X}$ and $\mathrm{Y}$ for each respondent

$\Sigma \mathrm{X}^{2}$ : the score of squared in $\mathrm{X}(\mathrm{X}$ is the score for each test item)

$\Sigma \mathrm{Y}^{2}$ : the score of squared in $\mathrm{Y}$ ( $\mathrm{Y}$ is the total correct answer score)

$\mathrm{N} \quad$ : the number of student taking the test

\section{Reliability of Test}

Reliability is a necessary characteristic of any good test, for it to be valid at all, a test must first be reliable as a measuring instrument Heaton (1979:155). Reliability of the test shows whether the instrument is reliable and can be used as device to collect the data. Reliability means the stability of test scores when the test is used. A test is reliable to the extent that it measures consistently, from one time 
to another. In this research, the writer tried to find out the reliability after computing the validity of the instrument. To measure the reliability of the test, the writer used the K.21. The formula is:

$$
r 11=\left(\frac{k}{k-1}\right)\left(1-\frac{M(k-M)}{k V t}\right.
$$

Arikunto (2006: 178)

In which:

$\mathrm{r}_{11} \quad$ : instrument reliability

$\mathrm{k} \quad$ : the number of items in the test

$\mathrm{M} \quad$ : the mean score on the test for all students

$\mathrm{V}_{\mathrm{t}}$ : the variance of the total score/the total variance

But, to make easy in analyzing the data, the researcher use SPSS. This way is very efficient,valuable and exacting in giving the real output.

\section{RESEARCH FINDINGS}

The distribution of the students' reading habit result :

\begin{tabular}{|c|c|c|c|}
\hline $\begin{array}{c}\text { Percentage } \\
\text { Interval }\end{array}$ & Criteria & $\begin{array}{c}\text { Frequen } \\
\text { cy }\end{array}$ & $\begin{array}{c}\text { Achievem } \\
\text { ent }\end{array}$ \\
\hline $81-100$ & Very Good & 0 & \\
\hline $61-80$ & Good & 20 & 58.82 \\
\hline $41-60$ & Fair & 13 & 38.23 \\
\hline $21-40$ & Bad & 1 & 2.94 \\
\hline Sum & & 34 & $100 \%$ \\
\hline Highest & $77.5 \%$ & \\
\hline Lowest & $33.75 \%$ \\
\hline Average & $61.1 \%$ \\
\hline
\end{tabular}

The distribution of the students' writing achievement result :

\begin{tabular}{|c|c|c|c|}
\hline $\begin{array}{c}\text { Percenta } \\
\text { ge } \\
\text { Interval }\end{array}$ & Criteria & $\begin{array}{c}\text { Frequenc } \\
\text { y }\end{array}$ & $\begin{array}{c}\text { Achieveme } \\
\text { nt }\end{array}$ \\
\hline $91-100$ & $\begin{array}{c}\text { Excelle } \\
\text { nt }\end{array}$ & 0 & 0 \\
\hline $81-90$ & $\begin{array}{c}\text { Very } \\
\text { Good }\end{array}$ & 7 & 20.59 \\
\hline $71-80$ & Good & 14 & 41.18 \\
\hline $61-70$ & $\begin{array}{c}\text { Averag } \\
\text { e }\end{array}$ & 9 & 26.47 \\
\hline $51-60$ & Fair & 3 & 8.82 \\
\hline $41-50$ & Poor & 1 & 2.94 \\
\hline Sum & & 34 & $100 \%$ \\
\hline Highest & & 85 & \\
\hline Lowest & & 47 & \\
\hline Average & & 72.4 & \\
\hline
\end{tabular}

Descriptive Statistics

\begin{tabular}{|l|l|l|l|}
\hline & Mean & Std. Deviation & $\mathrm{N}$ \\
\hline $\mathrm{X}$ & 48.4118 & 6.64292 & 34 \\
$\mathrm{Y}$ & 72.5882 & 8.78745 & 34 \\
\hline
\end{tabular}

The table above shows that, mean of reading habit 48.4118 and the std. deviation is 6.64292. Mean of the writing ability 72.5882 and the std deviation is 8.78745 .

\section{Correlations}

\begin{tabular}{|l|l|l|}
\hline & $\mathrm{X}$ & $\mathrm{y}$ \\
\hline $\mathrm{x} \quad$ Pearson Correlation & 1 & $.592^{* *}$ \\
& & .000 \\
Significance(2-tailed) & & \\
Sum of Squares and Cross- & 1456.235 & 1139.765 \\
products & & \\
Covariance & 44.128 & 34.538 \\
\hline
\end{tabular}




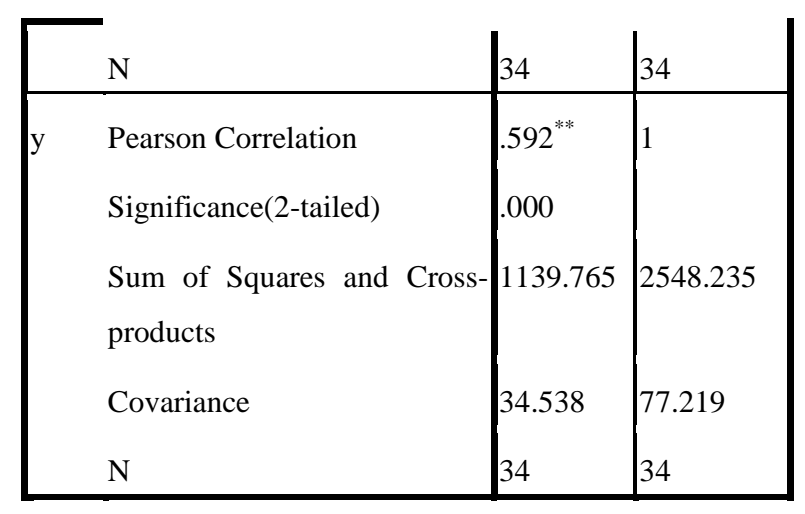

**. Correlation at $0.01(2$-tailed):...

From the table above, it showed that significant corrrelation was found of students reading habit score to their writing ability in narrative text. so, in the conclusion $p$ was 0.000 , the 2-tailed value was smaller than $\quad 0.05$ $(\mathrm{p}<0.05)$. the result showed that the score did correlate between students reading habit score to their writing ability in narrative text at senior high school 2 tambang. based on the analysis, the hyphotesis $\mathrm{H}_{\mathrm{a}}$ was accepted and $\mathrm{H}_{\mathrm{o}}$ rejected. so, it can be concluded "There is significant correlation between students reading habit and their writing ability in narrative text at State Islamic Senior High School 1 Pekanbaru.

\section{CONCLUSION}

The purpose of the research was to answer whether or not there is a significant correlation between students reading habit and their ability of writing narrative text. To obtain the intended data, the writer arranged the questionnaire test to measure how good is the reading habit of the eleventh graders and writing test to measure the students ability of writing narrative text. After conducting the research, the writer comes to some conclusions.

First, the reading habit of the eleventh grade students of MAN 1 Pekanbaru is good. It can be seen from the average score of the students questionnaire test is 60.1. When it is consulted to the table of category level by Arikunto, the score is categorized good.

Second, the writing ability of the eleventh grade students of MAN 1 Pekanbaru is also good. It can be seen from the computation in which the average score of the students writing ability is 72.4 . When it is consulted to the table of category level scores by Hyland, the score is categorized good.

Third, there is a significant positive correlation between students reading habit and their ability of writing narrative text on the eleventh grade of MAN 1 Pekanbaru in the academic year of 2017/2018.

Recalling the $\mathrm{r}_{\mathrm{xy}}$ observed value of the correlation between students reading habit and their ability of writing applied to the sample is 0.629 , and consulting to the critical values of the $r$ Product Moment with 95\% confidence level and the number of subjects 34 was 0.339 . It means that the result obtained from the computation is higher than its critical value. Therefore, the writer concludes that there is a significant positive correlation between students reading habit $(\mathrm{X})$ and their ability of writing narrative text (Y) on the eleventh grade of MAN 1 Pekanbaru. 


\section{REFERENCES}

Adler,C.R.ced. 2001. The Research Building Blocks for Teaching Children Reading Habit. National Institute for Literacy.

Creswell, John W.2011. Research Design Pendekatan Kualitatif, Kuantitatif, dan Mixed. Yogyakarta. Pustaka Pelajar.

Elley, W. and F, Mangubhai.1983.The Impact of Reading on Second Language Learning. Reading Reseach Quartely.

Galicia, Julio Cesar.2011. Relationship between Reading Habits, University Library and Academic Performance in A Sample of Psychology Students, Revista de La Educaion Superior Journal, Vol. XL (I) No. 157.

Heaton, J. B. 1979. Writing English Language Test. London: Longman Group Limited.

Hughey.Jane B.et.al.1983.ESL

Composition: Principle and Technique. London: Newbury House Publisher

Hyland,K.2003. Second Language Writing. New York: Cambridge University Press.

Jack, Steel. 2008 The Habit of Reading and its Advantages-Why You Should Develops Habit of Regular Reading. http://voice.yahoo.com/thehabit-its-advantages.com.

Johnson \& Pearson. 1984. Strategies for reading Comprehension.New York: Holt, Rinehart and Winston
Meyers, A. 2005. Gateways to Academic Writing: Effective Sentences Paragraph and Essay. New York: Longman.

Simon, M. and Goes, J. 2011. Correlational Research. Available at: dissertationrecipes.com/wpcontent/.../04/Correlationalresearc h.pdf accessed 2/28/15.

Suharsimi Arikunto. 2006. Prosedur Penelitian :Suatu Pendekatan Praktis. Jakarta: RhinekaCipta.

Syafi'i S, m.Fauzan Ansyari, and Jonri Kasdi. 2011. The Process of Writing for Classroom Settings. Pekanbaru: LSBI.

Sugiyono. 2005. Metode Penelitian Administrasi.Bandung: $\quad \mathrm{CV}$ Alfabeta.

Webb, S. 2008. Receptive and Productive Vocabulary Sizes of Second Language Learners. Studies in Second Language Acquisition.

Westwood. Peter. 2008. Reading and Writing Dificulties.Australia: ACER Press. 